\title{
INOVASI MODEL PEMBELAJARAN MELALUI PERMAINAN TRADISIONAL “LEMPAR KARET” UNTUK MENGAJARKAN KONSEP PERKALIAN BAGI SISWA SEKOLAH DASAR
}

\author{
Sri Hartatik, Dewi Widiana Rahayu \\ Universitas Nahdlatul Ulama Surabaya \\ e-mail: titax@unusa.ac.id
}

\begin{abstract}
Abstrak: Peningkatan pemahaman siswa terhadap konsep matematika dapat dilakukan melalui pembelajaran yang dirancang dengan mengembangkan permainan tradisional sebagai salah satu strategi guru dalam meningkatkan hasil belajar matematika. Selama ini permainan tradisional yang sering digunakan dalam pembelajaran matematika adalah permainan dakon. Artikel ini membahas tentang adanya inovasi dalam pembelajaran matematika melalui penerapan permainan tradisional lempar karet berbeda dengan permainan tradisional yang sebelumnya. Penulis merancang permainan tradisional lempar karet sebagai teknik dalam mengajarkan konsep perkalian pada siswa sekolah dasar. Model Pembelajaran ini bertujuan meningkatkan pemahaman matematika serta meminimalisasi kecemasan siswa dalam mempelajari matematika. Adapun tahapan-tahapan dalam model pembelajaran berbasis permainan tradisional adalah menyampaikan tujuan pembelajaran, membentuk kelompok, menyiapkan alat dan bahan, menjelaskan aturan permainan, mensimulasikan, melakukan permainan, membimbing kelompok, evaluasi dan menarik kesimpulan. Model Pembelajaran ini mempunyai beberapa prinsip yaitu ketergantungan positif, tanggung jawab perseorangan, sportif, partisipasi dan komunikasi, dan evaluasi proses kelompok dan individu.
\end{abstract}

Kata kunci: permainan tradisional "lempar karet”, model pembelajaran, konsep perkalian

\begin{abstract}
Increased understanding of the students for the mathematical concept can be done with a learning that is designed to develop the traditional game as one of the strategies of teachers in improving the results of learning math. During this traditional game that is often used in learning mathematics is a game of dakon. This article discusses the presence of innovation in learning mathematics through the application of traditional game is throwing a rubber that is different from the prior. Author of designing traditional rubber throwing games as a technique in teaching the concept of multiplication on elementary school students. This Learning model aimed at increasing the understanding of mathematics as well as minimize the anxiety of students in learning mathematics. As for the stages in traditional game-based learning model is delivering the learning objectives, form groups, set up tools and materials, explaining the rules of the game, simulate, doing the game, guide the group, evaluation and drawing conclusions. This Learning model has several principles, namely positive dependence, personal responsibility, sportsmanship, participation and communication, and evaluation process of the groups and individuals.
\end{abstract}

Keywords: traditional games "throw the rubber", a model of learning, the concept of multiplication

\section{A. PENDAHULUAN}

Matematika mempunyai objek abstrak yang bertumpu pada kesepakatan dan pola pikir deduktif. Dalam pembelajaran yang abstrak, siswa memerlukan alat bantu dalam merepre- sentasikan sesuatu yang abstrak. Tujuan dari pembelajaran matematika adalah melatih dan menumbuhkan cara berpikir yang logis, sistematis, kreatif dan konsisten serta mampu mengembangkan diri dalam menyelesaikan masalah. Ketidakmampuan siswa dalam menyelesaikan 
masalah matematika menjadi salah satu alasan utama siswa tidak menyukai matematika. Bahkan tidak hanya di level siswa sekolah dasar, calon guru sekolah dasar saja juga sangat cemas dengan keberadaan matematika hal ini dibuktikan dengan adanya Hasil penelitian menunjukkan angka yang fantastis dalam kasus kecemasan matematika pada guru SD yakni mencapai $22 \%$. Data tersebut menjadi asesmen awal dalam memperbaiki kualitas pembelajaran matematika di SD melalui aspek guru (Hartatik dan Fifi, 2017). Apabila calon guru sudah cemas terhadap matematika, bagaimana dengan kondisi siswanya. Ada beberapa hal yang menyebabkan kecemasan matematika antara lain: (1) karena pengajarnya, (2) materi (3), kemampuan intelektual matematika, (4) keterbatasan bahasa dan kurang PD, dan (5) matematika sulit (Marcus dan Pramana, 2015). Untuk mengatasi penyebab kecemasan belajar matematika perlu adanya perbaikan dalam pembelajaran matematika di samping itu pula diperlukan juga karakteristik pengajar yang bersahabat. Kemampuan untuk melakukan perkalian dan kemampuan menentukan bilangan sebagai jumlah, selisih, hasil kali, atau hasil bagi dua bilangan cacah dalam kehidupan sehari hari merupakan salah satu kompetensi yang harus di miliki oleh siswa sebagai dasar dalam menyelesaikan masalah yang terkait dengan materi perkalian dan penjumlahan. Pada prinsipnya konsep perkalian merupakan penjumlahan yang berulang. Untuk mengajarkan konsep perkalian kepada siswa sekolah dasar, maka terlebih dahulu siswa harus memahami konsep penjumlahan terlebih dahulu. Hal ini sejalan dengan apa yang disampaikan oleh (Walle, Karp, and Williams, 2008: 158-159).

"To make clear the connection to addition, early multiplication activities should also include writing and addition sentence for the same model."
Artinya, untuk memperjelas hubungan antara penjumlahan dan perkalian kegiatan awal perkalian harus menuliskan dan menjelaskan melalui konsep penjumlahan.

Strategi dalam mengajarkan konsep perkalian sangat beraneka ragam tergantung pada kemampuan perencanaan seorang guru dalam mendesain pembelajaran yang aktif, kreatif, efektif dan menyenangkan. Untuk mengurangi kecemasan siswa dalam belajar matematika dapat digunakan beberapa cara yaitu mendesain suatu pembelajaran yang aktif, kreatif, efektif dan menyenangkan. Menurut Dienes dalam Somakim (2008) menjelaskan bahwa tiap-tiap konsep matematika atau prinsip dalam matematika yang disajikan dalam bentuk yang konkret akan dapat dipahami dengan baik oleh siswa. Kemudian Somakin (2008) juga menegaskan bahwa bendabenda atau objek-objek dalam bentuk permainan akan sangat berperan apabila dimanipulasi dengan baik dalam pembelajaran matematika sehingga tujuan pembelajaran tercapai.

Permainan tradisional adalah permainan yang dimainkan oleh anak-anak zaman dahulu. Perkembangan teknologi yang mengikuti perkembangan saat ini perlahan-lahan menggeser keberadaan dari permainan tradisional. Saat ini Jarang sekali kita melihat anak-anak zaman sekarang khususnya anak-anak di perkotaan memainkan permainan tradisional seperti petak umpet, egrang, conglak, lompat tali, gatrik, engklek, pesawat-pesawatan, layang-layang dan kelereng. Hal ini dikarenakan semakin sempitnya area bermain anak. Permainan tradisional merupakan salah satu kearifan budaya lokal yang seharusnya dapat dilestarikan dan dimanfaatkan dalam pembelajaran psikomotorik dan kognitif anak justru tergeser dengan munculnya berbagai permainan yang dapat diunduh secara online di komputer atau gadget. Salah satu permainan tradisional yang dapat digunakan untuk meng- 
ajarkan konsep matematika yaitu konsep perkalian adalah permainan lempar karet.

Model pembelajaran berbasis permainan tradisional "lempar karet" dikembangkan dengan tujuan untuk meningkatkan pemahaman siswa terhadap konsep perkalian. Model tersebut juga dapat mengangkat kearifan budaya lokal suatu daerah yang sudah tergeser oleh komputer atau gadget. Berikut ini beberapa percobaan yang dilakukan oleh tim peneliti untuk menguji keefektifan model pembelajaran berbasis permainan tradisional "lempar karet" dalam meningkatkan pemahaman siswa.

\section{B. METODE}

Penelitian ini merupakan penelitian pengembangan. Adapun langkah-langkah penelitian pengembangan adalah mulai dari proses mengumpulkan informasi, desain model, validasi, perbaikan sampai dengan uji coba sampai dengan revisi sehingga menghasilkan model pembelajaran matematika yang berbasis permainan tradisional lempar karet.

\section{HASIL DAN PEMBAHASAN}

Model pembelajaran ini merupakan inovasi model pembelajaran yang menggunakan permainan tradisional "lempar karet" sebagai salah satu strategi dalam mengajarkan matematika. Model ini merupakan pengembangan dari model pembelajaran kooperatif yang menggunakan konsep permainan tradisional sebagai warisan budaya lokal masyarakat Indonesia khususnya daerah Surabaya yang telah dikembangkan peneliti sebagai salah satu model pembelajaran matematika. Implementasi dari model pembelajaran ini adalah dengan menggunakan teknik menghitung jumlah karet yang diperoleh dalam per- mainan lempar karet konsep perkalian. Berikut ini dipaparkan karakteristik, prinsip, alur model media dan langkah-langkah pembelajaran dalam model pembelajaran berbasis permainan tradisional.

\section{a. Karakteristik Model Pembelajaran berbasis permainan tradisional Lempar Karet}

Adapun beberapa karakteristik dari model pembelajaran ini adalah sebagai berikut.

Tabel 1 Karakteristik Model Pembelajaran Berbasis Permainan Tradisional

\begin{tabular}{|l|l|}
\hline Karakteristik & $\begin{array}{l}\text { Model pembelajaran berbasis } \\
\text { permainan tradisional }\end{array}$ \\
\hline Tujuan kognitif & $\begin{array}{l}\text { Informasi akademik tingkat } \\
\text { tinggi dan keterampilan inquiry. }\end{array}$ \\
\hline Tujuan sosial & Kerja kelompok dan kerjasama \\
\hline Struktur tim & 1 tim terdiri dari 2-4 orang \\
\hline $\begin{array}{l}\text { Pemilihan topik } \\
\text { pelajaran }\end{array}$ & $\begin{array}{l}\text { Penjumlahan dan perkalian, } \\
\text { kemampuan menyusun strategi }\end{array}$ \\
\hline Tugas Utama & $\begin{array}{l}\text { Siswa dapat menggunakan stra- } \\
\text { tegi bermain lempar karet de- } \\
\text { ngan membuat gulungan karet } \\
\text { dengan jumlah tertentu sehing- } \\
\text { ga diharapkan akan memper- } \\
\text { oleh karet terbanyak di akhir } \\
\text { permainan, sehingga siswa da- } \\
\text { pat menemukan konsep perka- } \\
\text { lian dari penjumlahan yang } \\
\text { berulang. }\end{array}$ \\
\hline Penilaian & $\begin{array}{l}\text { Observasi kelompok tes lembar } \\
\text { kerja }\end{array}$ \\
\hline
\end{tabular}

\section{b. Prinsip-Prinsip Model Pembelajaran Berbasis permainan "Lempar karet"}

Model pembelajaran Berbasis permainan tradisional ini merupakan pengembangan dari model pembelajaran kooperatif, oleh karena itu maka prinsip yang ada pada Model pembelajaran berbasis permainan tradisional mengadopsi prin- 
sip yang ada pada model pembelajaran kooperatif, yaitu sebagai berikut.

1. Prinsip ketergantungan positif

Dalam pembelajaran ini, keberhasilan kelompok tergantung pada kerjasama tim dalam menyusun strategi untuk memenangkan pertandingan dalam hal ini permainan lempar karet.

2. Tanggung jawab perseorangan

Masing-masing anggota dalam tim mempunyai tugas masing-masing dalam permainan sehingga keberhasilan tim tergantung pada masingmasing anggota kelompoknya. Di dalam satu tim, antara anggota yang satu dan yang lain saling bertukar posisi (tugas) sehingga masingmasing anggota sama sama merasakan di setiap posisi di satu tim kerja.

3. Sportif

Dalam permainan ini di utamakan permainan yang sportif artinya menjunjung tinggi kejujuran.

4. Partisipasi dan komunikasi

Pada proses pembelajaran ini, perlu adanya partisipasi dan komunikasi antar-anggota dalam satu tim permainan. Karena keberhasilan suatu proses sangat dipengaruhi oleh partisipasi dan komunikasi dari anggota lain dalam satu tim.

5. Evaluasi proses kelompok dan individu.

Keberhasilan suatu model pembelajaran dapat diukur dari hasil evaluasi yang diperoleh secara kelompok dan individu.

\section{c. Media Permainan Lempar Karet}

Permainan lempar karet merupakan permainan tradisional yang menggunakan karet gelang sebagai media utama dalam permainan tersebut. Berikut ini beberapa media yang digunakan dalam permainan lempar karet.
1. Karet gelang

Karet gelang adalah potongan-potongan karet yang menyerupai gelang yang dapat digunakan untuk mengikat barang. Karet gelang mempunyai ukuran yang beragam mulai dari yang kecil sampai besar, dari yang tebal sampai yang tipis. Gambar 1 merupakan contoh karet gelang.

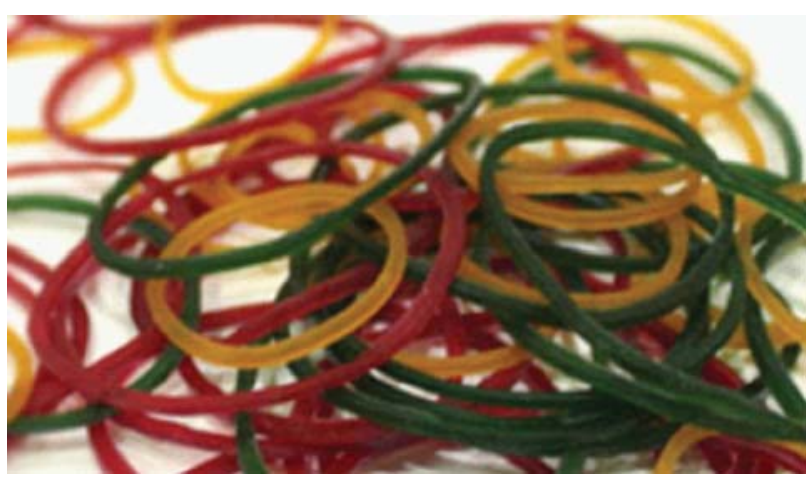

Gambar 1 Karet Gelang

2. Area pelemparan

Untuk area pelemparan bisa menggunakan ubin atau lantai kemudian lantai atau ubin dapat dilukis dengan menggunakan spidol atau kapur tulis seperti terlihat pada Gambar 2.

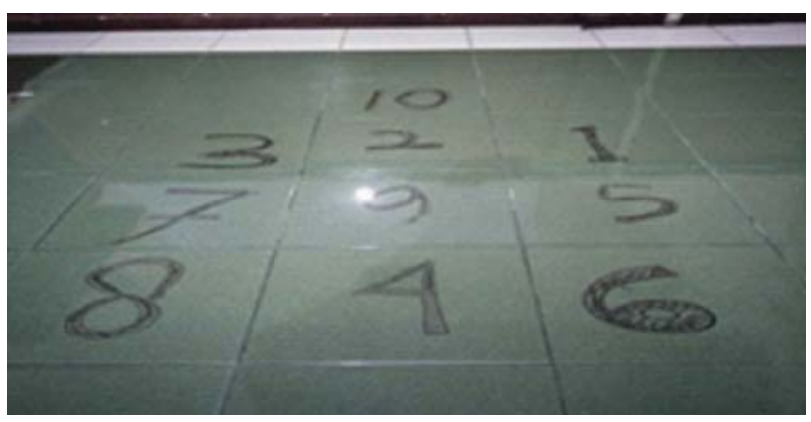

Gambar 2a Area Pelemparan Karet dari Ubin

Media pelemparan karet dapat dikembangkan dengan menggunakan media yang terbuat dari tripleks, karton atau sejenisnya lihat gambar 2.b. Papan tripleks berisikan angka 1 sampai sepuluh. Sebelum memulai permainan lempar karet, papan untuk area pelemparan dapat disusun seperti Gambar 2.b. Angka disusun urut atau acak. 
Sri Hartatik, Dewi Widiana Rahayu, Inovasi Model Pembelajaran Melalui Permainan Tradisional "Lempar Karet" untuk Mengajarkan Konsep Perkalian bagi Siswa Sekolah Dasar

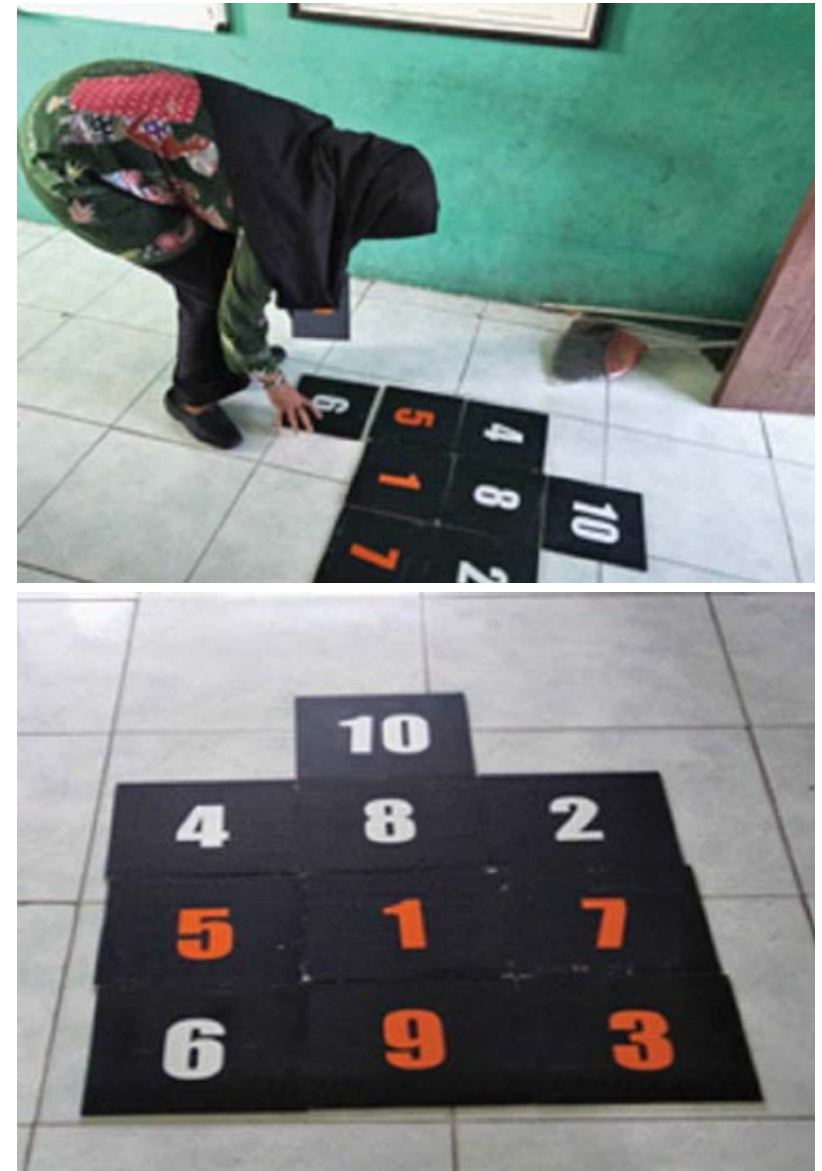

Gambar 2b Area Pelemparan Karet dari Tripleks

3. Tabel skor/nilai

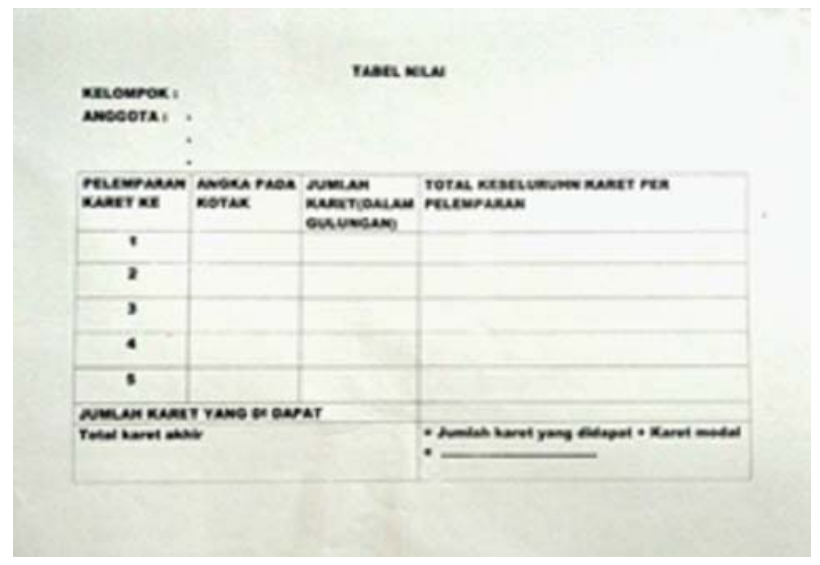

Gambar 3 Tabel Nilai

Tabel ini berfungsi sebagai media dalam mencatat skor perolehan karet yang diperoleh tim selama 5 kali pelemparan.

\section{d. Langkah-Langkah Pembelajaran}

Model pembelajaran berbasis permainan tradisional terdiri dari 9 tahapan seperti tampak pada Gambar 4.

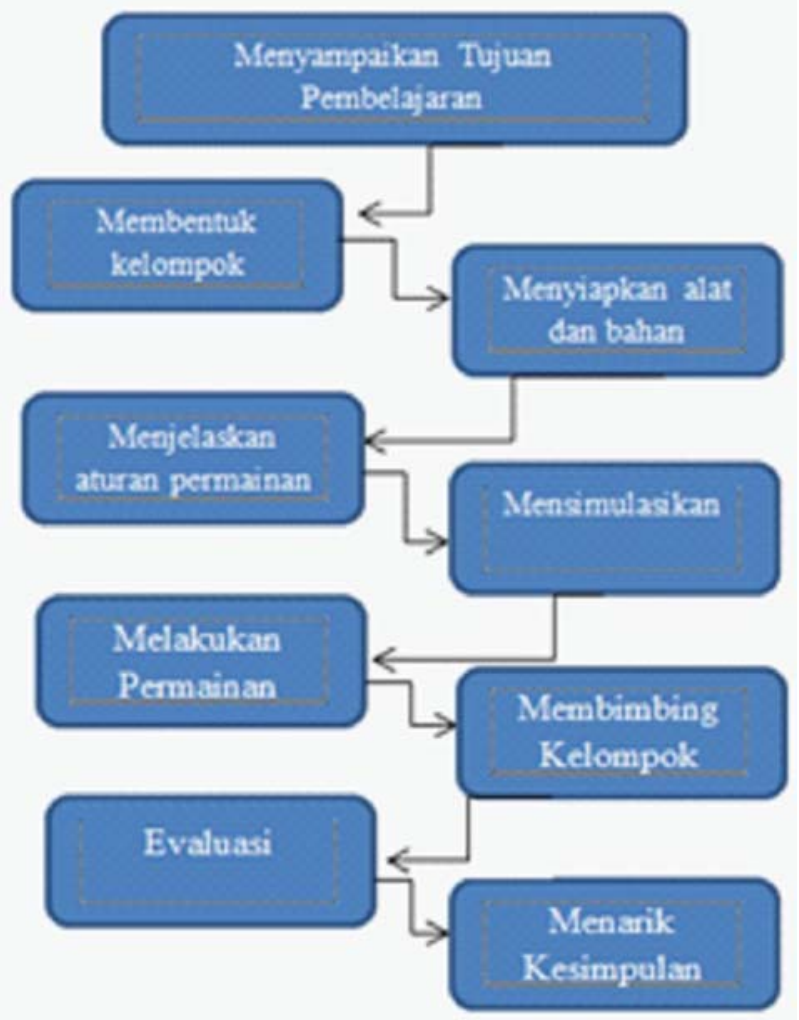

Gambar 4 Alur Model Pembelajaran Berbasis Permainan Tradisional

Alur model pembelajaran berbasis permainan tradisional terdiri dari 9 tahapan yang tergambarkan pada langkah-langkah pembelajaran di bawah ini.

Tahap 1: menyampaikan tujuan pembelajaran Sebelum melakukan pembelajaran guru menyampaikan tujuan pembelajaran terlebih dahulu sehingga siswa mengetahui tujuan pembelajaran.

Tahap 2: membentuk kelompok

Guru terlebih dahulu membagi siswa dalam flat-flat permainan. Setiap 1 role permainan dinamakan "flat". Di dalam 1 kelas bisa dibentuk 
menjadi beberapa flat. Setiap flat terdiri dari beberapa tim, 1 tim terdiri dari 2 orang. Satu orang berfungsi sebagai pencatat skor dan yang satunya berfungsi sebagai pelempar karet ke medan area pelemparan. Untuk fungsinya dalam setiap tim boleh bergantian fungsi.

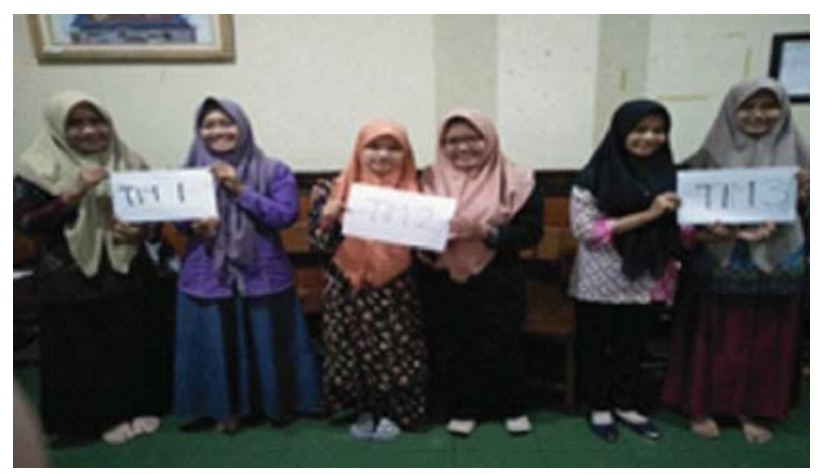

Gambar 5 Siswa dibagi Menjadi Beberapa Tim

Tahap 3: mempersiapkan alat dan bahan serta arena permainan lempar karet.

Guru terlebih dahulu mempersiapkan alat dan bahannya seperti karet, kertas penskoran, arena permainan lempar karet dan batas pelemparan. Kemudian membagikan kepada karet setiap tim. Untuk lebih jelasnya seperti tampak pada kegiatan-kegiatan di bawah ini.

a. Menyiapkan karet kemudian membagi karet untuk masing-masing tim yang terdiri dari 10-15 karet sebagai modal masing-masing tim. Masing-masing tim memperoleh jumlah karet yang sama.

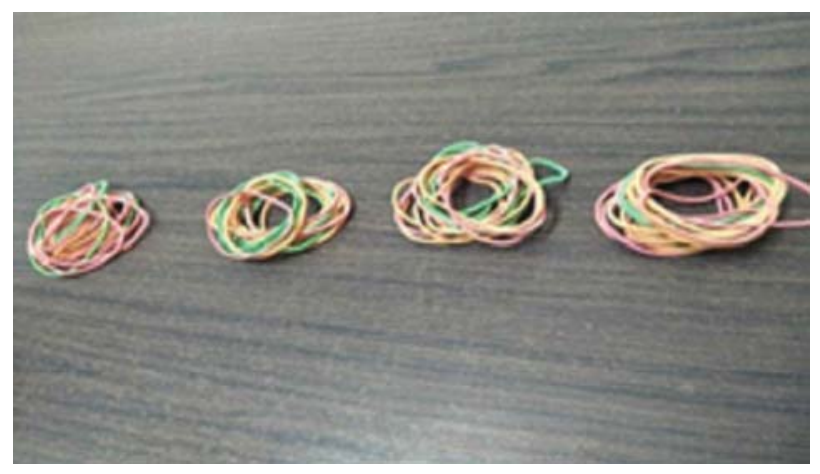

Gambar 6 Karet yang Sudah Disiapkan untuk Dibagi, Masing-Masing Sejumlah 15 Karet. b. Membagikan karet kepada masing-masing tim

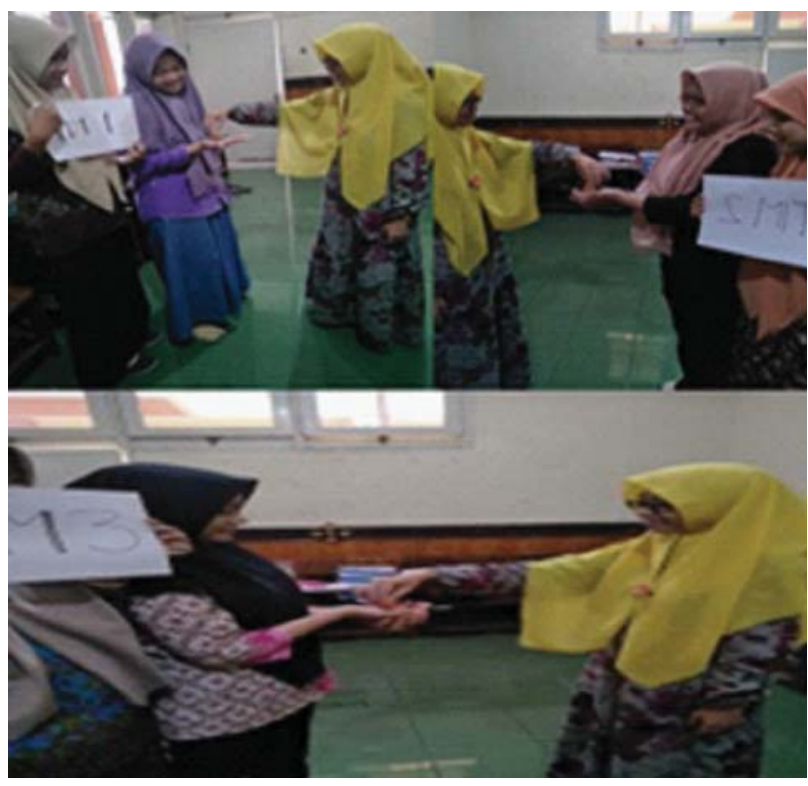

Gambar 7 Guru Membagikan Karet kepada Seluruh Tim

c. Membuat kotak area pelemparan karet dan batas pelemparan karet. Arena permainan bisa dibuat di dalam kelas atau di luar kelas.

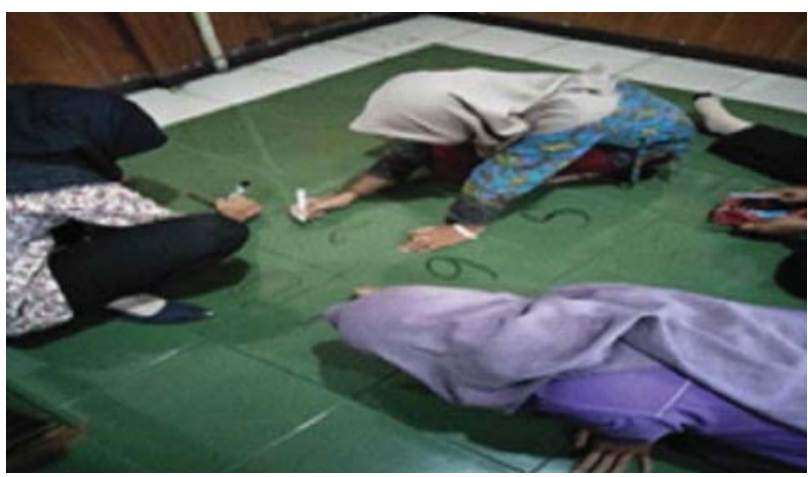

Gambar 8 Membuat Area Pelemparan di Lantai Kelas dengan Spidol

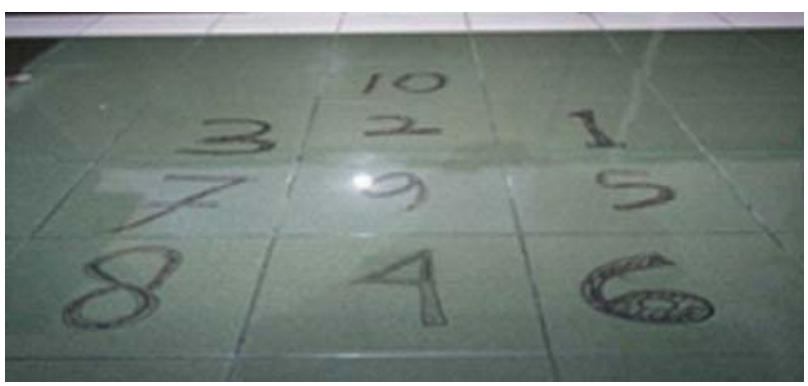

Gambar 9 Area Pelemparan yang Selesai Dibuat 


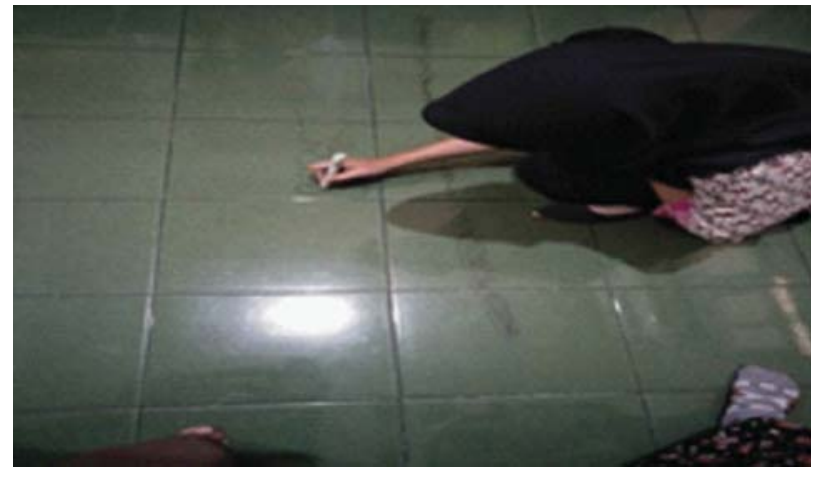

Gambar 10 Membuat Batas Pelemparan dengan Spidol

d. Menyiapkan kertas/papan untuk mencatat skor.
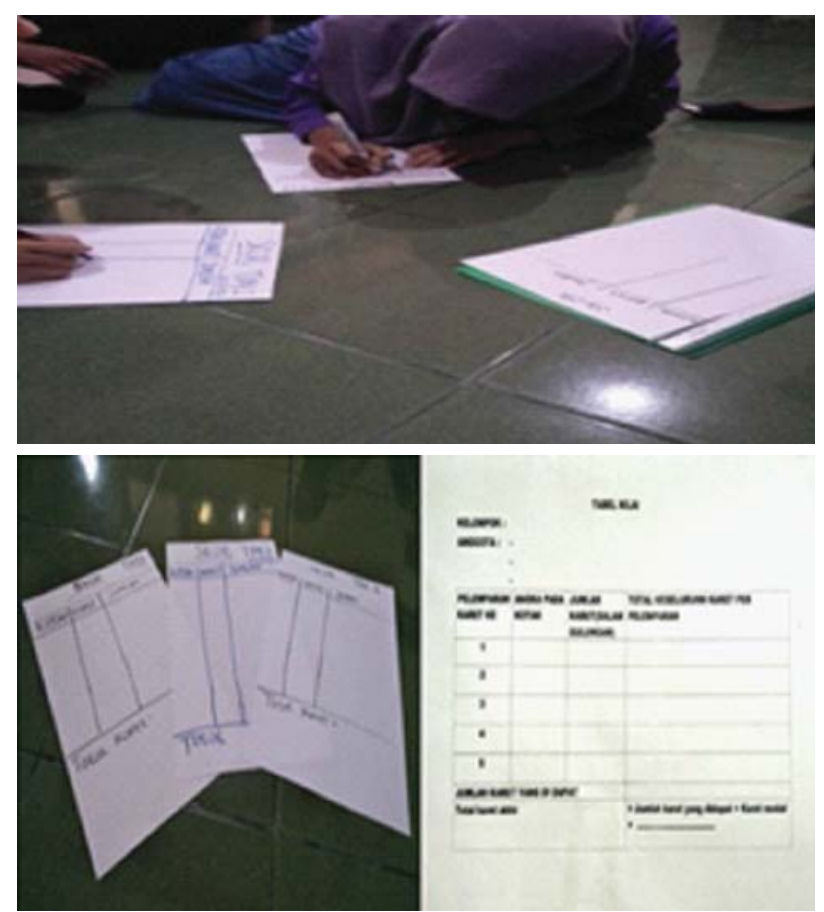

Gambar 11 Menyiapkan Tabel Nilai/Skor

Tahap 4: menjelaskan aturan permainan Guru menjelaskan kepada siswa tentang aturanaturan permainan "lempar karet" adalah sebagai berikut.

a. Masing-masing tim memperoleh kesempatan 5 kali pelemparan (banyak pelemparan bisa disesuaikan dengan waktu pelaksanaan).

b. Masing-masing tim memperoleh modal karet sebanyak 15 buah. Dari 15 buah karet terse- but dibuat 5 buah gulungan karet dengan jumlah masing-masing gulungan tergantung pada komposisi jumlah yang dibuat masingmasing tim.

c. Contoh: dari 3 karet akan dibuat sebuah gulungan karet. Gulungan karet tersebut akan dilemparkan ke arena pelemparan.

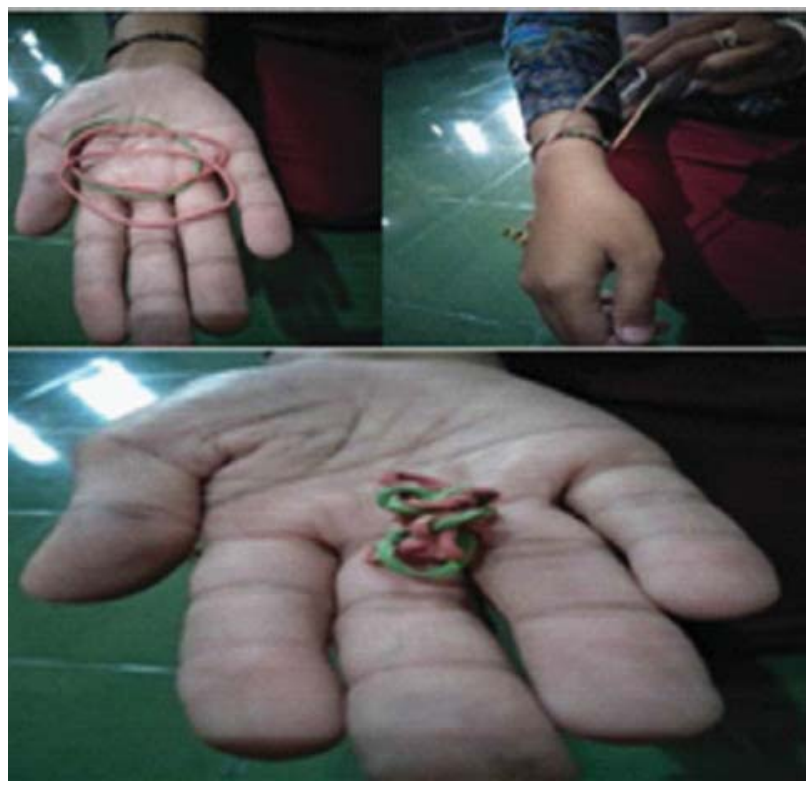

Gambar 12 Proses Pembuatan Gulungan Karet

d. Karet dilempar ke kotak area pelemparan

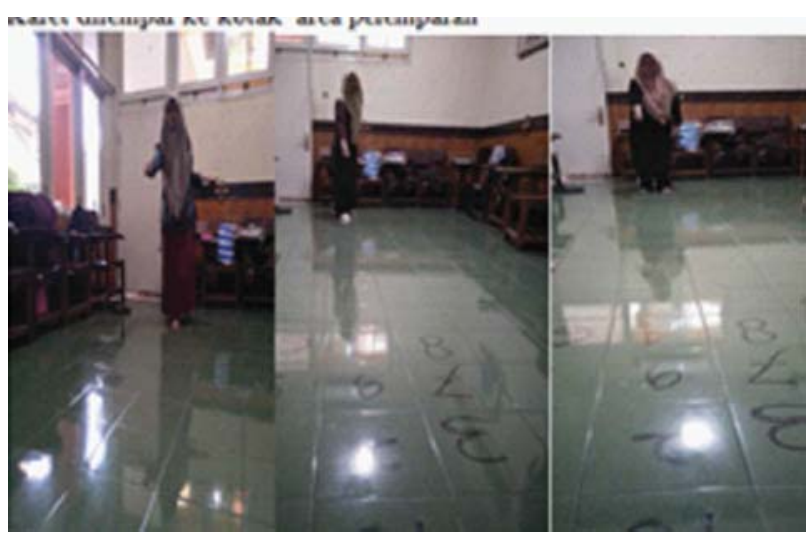

Gambar 13 Teknik Melempar Karet

Jika karet yang dilempar masuk ke kotak area pelemparan dan tidak menyentuh garis maka tim akan memperoleh karet dari bank karet sejumlah: 


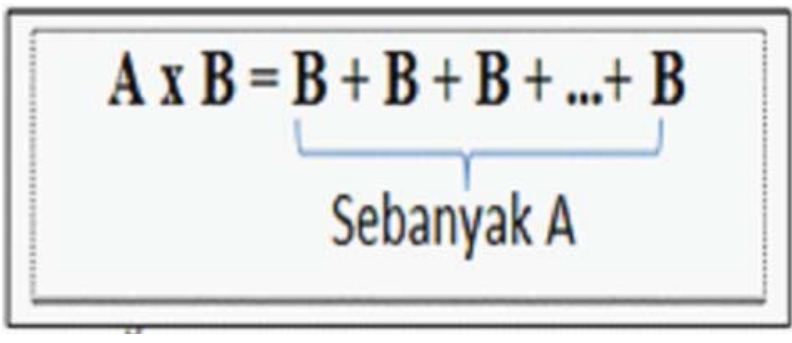

Keterangan:

$\mathrm{A}=$ angka dalam area pelemparan

$\mathrm{B}=$ jumlah karet dalam gulungan

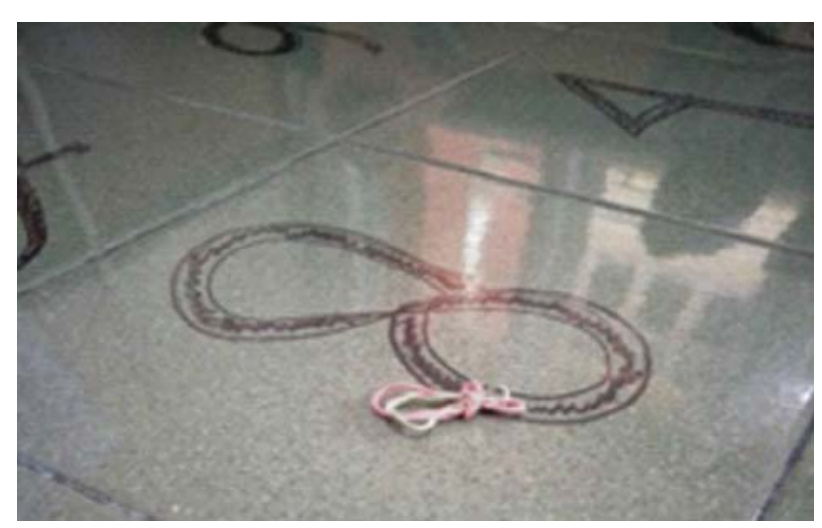

Gambar 14 Contoh Gulungan Karet yang Masuk Area Pelemparan dan Tidak Terkena Garis

Misalkan: jika $\mathrm{A}=$ angka yang ada di kotak adalah 8 dan $\mathrm{B}$ adalah jumlah karet yang dilempar adalah 3 maka

$$
\begin{aligned}
8 \times 3 & =3+3+3+3+3+3+3+3 \\
& =24
\end{aligned}
$$

Jadi banyaknya karet yang diperoleh sebanyak 24 karet

Jika karet yang dilempar keluar atau mengenai garis maka tim tidak akan memperoleh karet bahkan karet lemparan harus diambil sehingga mengurangi modal dari tim.
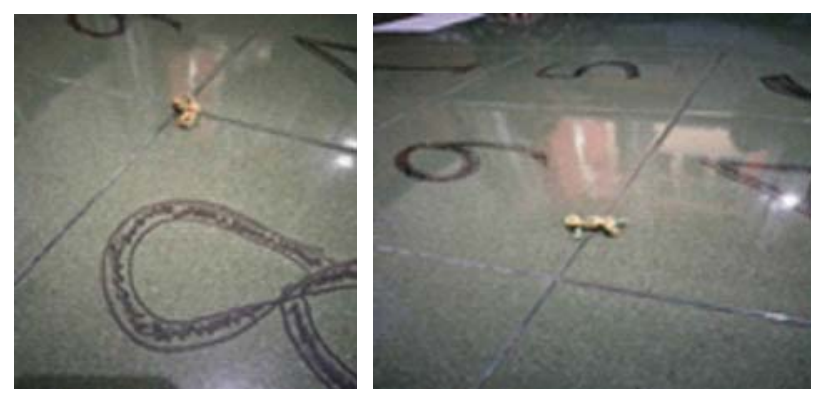

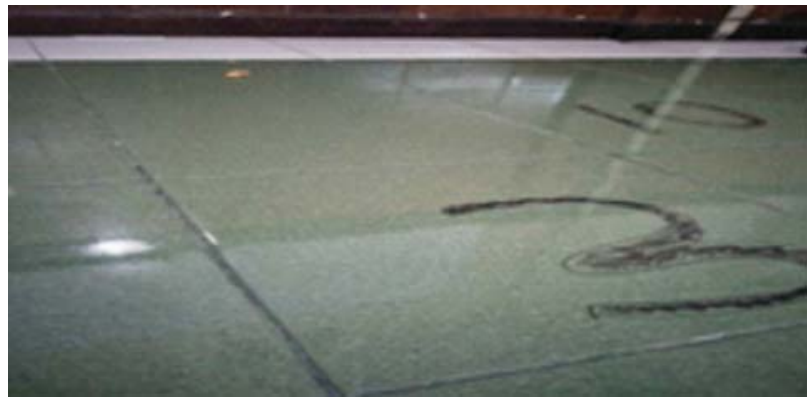

Gambar 15 Contoh Gulungan Karet yang Keluar Area Pelemparan

Kesempatan pelemparan masing-masing tim diberikan sebanyak 5 kali.

Tahap 5: simulasi

Guru memberikan contoh dengan mensimulasikan bagaimana cara bermain lempar karet.

Tahap 6: memulai permainan

Guru memberikan instruksi kepada siswa untuk memulai permainan lempar karet sesuai dengan aturan yang sudah diberikan guru.

Tahap 7: membimbing kelompok

Guru mengamati jalannya permainan dari masingmasing flat dan memberikan bimbingan kepada masing-masing kelompok.

Tahap 8: evaluasi

Guru memberikan kesempatan kepada masingmasing tim untuk mempresentasikan hasil karet yang didapatkan selama permainan.

Contoh:

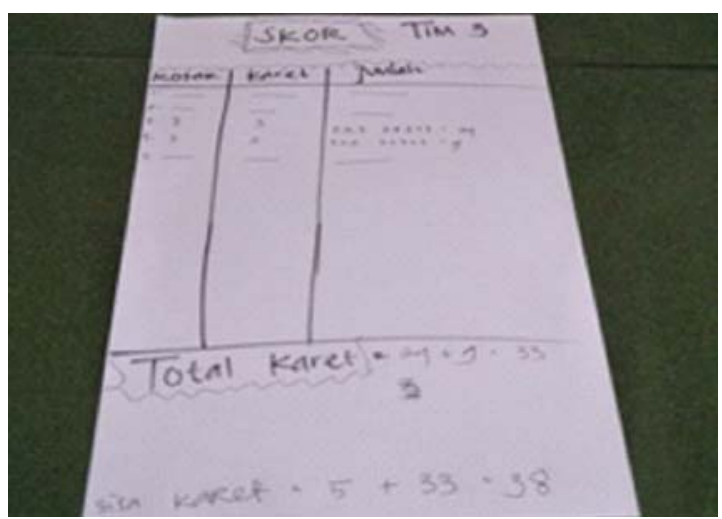


Dari 5 kali kesempatan pelemparan diperoleh hasil sebagai berikut.

1. Pelemparan gagal

2. Pelemparan gagal

3. Angka di kotak 8 dan jumlah karet dalam gulungan 3 sehingga jumlah karet yang di peroleh:

$8 \times 3=3+3+3+3+3+3+3+3=24$

4. Angka di kotak 3 dan jumlah karet dalam gulungan 2 sehingga jumlah karet yang diperoleh $3 \times 2=2+2+2=6$

5. Pelemparan gagal

Jumlah karet yang diperoleh adalah $=24+$ $6+5$ (sisa karet modal) $=35$

Dari contoh diatas, siswa melakukan kesalahan perhitungan pada pelemparan ke empat sehingga guru menginstruksikan untuk melakukan perbaikan sambil menunjukkan jawaban yang benar.

Tahap 9: menarik kesimpulan

Guru bersama siswa menyimpulkan hasil permainan dengan menemukan konsep perkalian sebagai berikut.

Dengan demikian, sebuah proses pembelajaran matematika melalui permainan karet dapat meningkatkan pemahaman peserta didik terhadap konsep perkalian. Langkah-langkah pembelajaran ini dapat diterapkan dalam satu kali pertemuan, karena langkah-langkah tersebut merupakan tahapan-tahapan yang harus dilaksanakan dalam model pembelajaran ini sehingga tujuan pembelajaran bisa tercapai. Pada prin-

Tabel 2 Rubrik Penilaian Keterampilan Siswa dalam Melakukan Permainan Lempar Karet

\begin{tabular}{|c|c|c|c|c|c|}
\hline \multirow{2}{*}{ No. } & \multirow{2}{*}{ Kriteria } & Baik sekali & Baik & Cukup & Perlu Bimbingan \\
\hline & & 4 & 3 & 2 & 1 \\
\hline 1 & $\begin{array}{l}\text { Kemampuan } \\
\text { menyusun } \\
\text { strategi }\end{array}$ & $\begin{array}{l}\text { Siswa mampu } \\
\text { menyusun stra- } \\
\text { tegi dengan sa- } \\
\text { ngat baik dalam } \\
\text { permainan } \\
\text { Lempar karet }\end{array}$ & $\begin{array}{l}\text { Siswa mampu } \\
\text { menyusun stra- } \\
\text { tegi dengan baik } \\
\text { dalam permain- } \\
\text { an Lempar karet }\end{array}$ & $\begin{array}{l}\text { Siswa cukup } \\
\text { mampu menyu- } \\
\text { sun strategi da- } \\
\text { lam permainan } \\
\text { Lempar karet }\end{array}$ & $\begin{array}{l}\text { Siswa kurang } \\
\text { mampu menyu- } \\
\text { sun strategi da- } \\
\text { lam permainan } \\
\text { Lempar karet }\end{array}$ \\
\hline 2 & $\begin{array}{l}\text { Kemampuan } \\
\text { Menjalankan } \\
\text { peraturan } \\
\text { permainan }\end{array}$ & $\begin{array}{l}\text { Siswa mampu } \\
\text { melakukan per- } \\
\text { mainan sesuai } \\
\text { instruksi yang } \\
\text { diberikan }\end{array}$ & $\begin{array}{l}\text { Siswa mampu } \\
\text { melakukan per- } \\
\text { mainan dengan } \\
\text { pengulangan in- } \\
\text { struksi sebanyak } \\
1 \text { kali }\end{array}$ & $\begin{array}{l}\text { Siswa mampu } \\
\text { melakukan per- } \\
\text { mainan dengan } \\
\text { pengulangan } \\
\text { instruksi lebih } \\
\text { dari } 1 \text { kali }\end{array}$ & $\begin{array}{l}\text { Siswa belum } \\
\text { mampu melaku- } \\
\text { kan permainan } \\
\text { sesuai dengan in- } \\
\text { struksi }\end{array}$ \\
\hline 3 & $\begin{array}{l}\text { Kemampuan } \\
\text { ketepatan } \\
\text { melakukan } \\
\text { pelemparan } \\
\text { karet ke area } \\
\text { pelemparan }\end{array}$ & $\begin{array}{l}\text { Siswa mampu } \\
\text { melempar karet } \\
\text { dengan akurat } \\
\text { (Masuk area dan } \\
\text { tidak kena garis) }\end{array}$ & $\begin{array}{l}\text { Siswa mampu } \\
\text { melempar karet } \\
\text { dan mengenai } \\
\text { garis permainan } \\
\text { (masuk area pe- } \\
\text { lemparan dan } \\
\text { kena garis) }\end{array}$ & $\begin{array}{l}\text { Siswa mampu } \\
\text { melempar karet } \\
\text { di luar area pe- } \\
\text { lemparan }\end{array}$ & $\begin{array}{l}\text { Siswa belum } \\
\text { mampu melem- } \\
\text { par karet (keluar } \\
\text { sangat jauh di } \\
\text { area pelemparan) }\end{array}$ \\
\hline
\end{tabular}


sipnya model pembelajaran berbasis permainan tradisional ini dapat memberikan kesenangan kepada peserta didik sehingga dapat mengurangi kecemasan dalam belajar matematika.

\section{a. Evaluasi Hasil Pembelajaran}

Evaluasi sangat penting dalam proses pembelajaran. Evaluasi pembelajaran pada model pembelajaran ini menekankan pada evaluasi kelompok dan evaluasi individu. Untuk instrumen evaluasi kelompok berupa lembar observasi kelompok dan untuk penilaian pemahaman konsep perkalian siswa dapat menggunakan tes tulis atau lisan.

Pada Tabel 2 ditunjukkan rubrik penilaian keterampilan siswa dalam melakukan permainan lempar karet.

\section{SIMPULAN}

Permainan tradisional adalah permainan yang dimainkan anak zaman dahulu. Permainan tradisional dapat di kelas menjadi suatu model pembelajaran yang inovatif sehingga kemampuan siswa dalam memahami konsep matematika meningkat. Konsep dasar model pembelajaran berbasis tradisional lempar karet adalah menggunakan permainan lempar karet sebagai teknik dalam mengajarkan konsep perkalian pada siswa sekolah dasar. Model Pembelajaran ini bertujuan meningkatkan pemahaman matematika serta meminimalisasi kecemasan siswa dalam mempelajari matematika.
Adapun tahapan-tahapan dalam model pembelajaran berbasis permainan tradisional adalah menyampaikan tujuan pembelajaran, membentuk kelompok, menyiapkan alat dan bahan, menjelaskan aturan permainan, mensimulasikan, melakukan permainan, membimbing kelompok, evaluasi dan menarik kesimpulan. Model Pembelajaran ini mempunyai beberapa prinsip yaitu ketergantungan positif, tanggung jawab perseorangan, sportif, partisipasi dan komunikasi, dan evaluasi proses kelompok dan individu.

\section{E. DAFTAR RUJUKAN}

Aisyah, Nyimas, dkk. 2008. Pengembangan Pembelajaran Matematika SD. Jakarta: Dirjen Dikti.

Chritine Lerin. 2009. 105 Permainan untuk Meningkatkan Kecerdasan \& Kreativitas Buah Hati. https://books.google.co.id/books? isbn $=9797990842$ di akses pada tanggal 10 April 2018.

Hartatik dan Fifi. 2017. Identifikasi Kecemasan Matematika Pada Mahasiswa Program Studi Pendidikan Guru Sekolah Dasar. Jurnal Bimbingan Konseling Indonesia (JBKI).

Maskur dan Pramana. 2015. Penyebab Kecemasan Matematika Mahasiswa Calon Guru Asal Papua. Jurnal Elemen, Vol. 1, No. 1, Januari 2015.

Walle, Karp and Williams. 2008. Elementary Middle School Mathematics. Teaching Developmentally. United States of America: Person Education, Inc. 